\title{
Dura Pharmaceuticals, Inc. v. Broudo: A Missed Opportunity to Right the Wrongs in the PSLRA and Rebalance the Private Rule 10b-5 Litigation Playing Field
}

Thomas F. Gillespie III

Follow this and additional works at: https://digitalcommons.law.umaryland.edu/jbtl

Part of the Civil Procedure Commons

\section{Recommended Citation}

Thomas F. Gillespie III, Dura Pharmaceuticals, Inc. v. Broudo: A Missed Opportunity to Right the Wrongs in the PSLRA and Rebalance the Private Rule 10b-5 Litigation Playing Field, 3 J. Bus. \& Tech. L. 161 (2008) Available at: https://digitalcommons.law.umaryland.edu/jbtl/vol3/iss1/11

This Notes \& Comments is brought to you for free and open access by the Academic Journals at DigitalCommons@UM Carey Law. It has been accepted for inclusion in Journal of Business \& Technology Law by an authorized editor of DigitalCommons@UM Carey Law. For more information, please contact smccarty@law.umaryland.edu. 


\section{Dura Pharmaceuticals, Inc. v. Broudo: A Missed Opportunity to Right the Wrongs in the PSLRA and Rebalance the Private Rule 10b-5 Litigation Playing Field}

In Dura Pharmaceuticals, Inc. V. Broudo the U.S. Supreme Court considered whether the Ninth Circuit's "inflated purchase price" approach to proving loss causation was consistent with the applicable federal securities laws, specifically the Private Securities Litigation Reform Act of $1995^{2}$ (PSLRA). The Court held that it was not, explaining that plaintiffs must prove that they have suffered an actual economic loss in order to satisfy the loss causation requirement of a Rule $10 \mathrm{~b}-5$ securities fraud claim. ${ }^{3}$ The Court also found that the plaintiffs' complaint was insufficient as a matter of law because it made no mention of any financial injury other than alleging that the plaintiffs paid artificially inflated purchase prices. ${ }^{4}$ In reaching this decision, the Court chose not to provide affirmative guidance with respect to which pleading standard applies to plaintiffs' loss causation pleadings. ${ }^{5}$ Nonetheless, the Court reversed the Ninth Circuit and remanded the case with instructions to dismiss. ${ }^{6}$

Though Dura is good law, it falls far short of being the landmark decision for which many commentators had hoped. ${ }^{7}$ In Dura, the Court faced several important issues: (1) whether loss causation is a separate and distinct element of a Rule 10b-5 securities fraud claim; (2) if so, what factual predicates constitute a showing thereof; and (3) what pleading standard applies to it? The Court only chose to

* J.D., University of Maryland School of Law, 2006. The author is the Technology Transfer Associate for the J. Craig Venter Institute (JCVI), a mid-sized non-profit independent genomics and proteomics laboratory.

1. 544 U.S. $336(2005)$

2. Pub. L. No. 104-67, 109 Stat. 737 (codified as amended in scattered sections of 15 U.S.C.).

3. Dura Pharms., 544 U.S. at 336.

4. Id. at 337 .

5. See id. (stating that the Court need not reach the issue of whether or not the higher standard described in the PSLRA applies to a plaintiffs' loss causation pleadings because the plaintiffs in the case at bar could not even satisfy a notice pleading standard); see also Fed. R. Civ. P. 8(a)(2).

6. Dura Pharms., 544 U.S. at 337.

7. See Ann Morales Olazabal, Loss Causation in Fraud-on-the-Market Cases Post-Dura Pharmaceuticals, 3 BERKeley Bus. L.J. 337, 341 (2006) (observing that many commentators expected affirmative guidance as to what must be pled and proven in order to properly show economic loss and/or loss causation when the Court granted certiorari). 
affirmatively answer the first question. In so doing, it took a positive step toward effectuating the congressional intent that undergirds the PSLRA, which was to make it more difficult for plaintiffs to bring frivolous securities fraud lawsuits. ${ }^{8}$ In choosing not to offer affirmative guidance with respect to the latter two questions, however, the Court effectively ignored the most important issues presented in Dura.

Affirmative answers regarding how economic loss can be pled, and the extent to which it must be pled in order to survive a $12(\mathrm{~b})(6)$ motion to dismiss, would have profoundly impacted how securities fraud cases are litigated. This Note argues that the Court should have expressly stated: (1) that it was adopting the out-of-pocket measure of damages for fraud-on-the market securities fraud cases; (2) that loss causation must be pled with particularity and that the preferred way to plead loss causation is to demonstrate that there was a drop in the price of the defendant's stock that can be contemporaneously linked to a corrective disclosure; and (3) that if plaintiffs cannot demonstrate loss causation via allegations of a corrective disclosure price drop, they must allege facts in their complaint that evince the existence of a significant nexus between the defendant's misrepresentation and their alleged economic injury. Such a holding would have been consistent with the congressional intent undergirding the passage of the PSLRA, and would have struck the appropriate balance between disallowing strike suits and facilitating the flow of legitimate cases to trial.

\section{THE CASE}

Michael Broudo, along with other members of the class, purchased shares of Dura Pharmaceuticals, Inc. common stock between April 15, 1997 and February 24, 1998. ${ }^{9}$ During that period, Dura issued several press releases indicating that its Albuterol Spiros Device, an asthma medication delivery product, had been adequately tested and was almost ready to go to market. ${ }^{10}$ Dura allegedly made these statements despite knowledge to the contrary. ${ }^{11}$ During the class period, Dura's stock price increased, reaching a high of $\$ 53$ per share. ${ }^{12}$ On the last day of the class period, Dura issued another release stating that it expected lower-than-forecasted revenues and earnings for 1998 because of slower-than-expected sales of another product, Ceclor CD. ${ }^{13}$ Dura's stock price dropped 47 percent on the day of this

8. See H.R. ReP. No. 104-369, at 41 (1995) (Conf. Rep.), reprinted in 1995 U.S.C.C.A.N. 679, 740 (stating that Rule 9(b) of the Federal Rules of Civil Procedure, which requires that allegations of fraud be pleaded with "particularity," has not deterred "professional" securities fraud plaintiffs and their counsel from filing meritless lawsuits, and that there is still a "need to establish uniform and more stringent pleading requirements to curtail the filing of meritless lawsuits" (emphasis added)).

9. Broudo v. Dura Pharms., Inc., 339 F.3d 933, 935 (9th Cir. 2003), rev'd, 544 U.S. 336 (2005).

10. Id.

11. Id.

12. Id. at 936.

13. Id. 
announcement and for the remainder of the year, its business declined. ${ }^{14}$ Dura later announced that its Albuterol Spiros Device would not go to market because the Food and Drug Administration refused to authorize it. ${ }^{15}$ This announcement came after the class period closed. ${ }^{16}$

Michael Broudo filed several class action suits on behalf of himself and other similarly situated investors, claiming that Dura's conduct during the class period violated section 10(b) of the Securities and Exchange Act of 1934, ${ }^{17}$ section 20(a) of the ' 34 Act, ${ }^{18}$ and Securities and Exchange Commission (SEC) Rule 10b-5. ${ }^{19}$ The

14. Id.
15. Id.
16. Id.
17. Section $10(\mathrm{~b})$ of the Securities and Exchange Act of 1934 is titled, "Manipulative and deceptive devices," and states that:

It shall be unlawful for any person, directly or indirectly, by the use of any means or instrumentality of interstate commerce or of the mails, or of any facility of any national securities exchange-

(b) To use or employ, in connection with the purchase or sale of any security registered on a national securities exchange or any security not so registered, or any securities-based swap agreement (as defined in section 206B of the Gramm-Leach-Bliley Act), any manipulative or deceptive device or contrivance in contravention of such rules and regulations as the Commission may prescribe as necessary or appropriate in the public interest or for the protection of investors.

15 U.S.C. $\$ 78 \mathrm{j}(2000)$.

18. Section 20(a) of the Securities and Exchange Act of 1934 is titled, "Liability of Controlling Persons and Persons Who Aid and Abet Violations." It states that:

(a) Joint and several liability; good faith defense. Every person who, directly or indirectly, controls any person liable under any provision of this chapter or of any rule or regulation thereunder shall also be liable jointly and severally with and to the same extent as such controlled person to any person to whom such controlled person is liable, unless the controlling person acted in good faith and did not directly or indirectly induce the act or acts constituting the violation or cause of action.

(b) Unlawful activity through or by means of any other person. It shall be unlawful for any person, directly or indirectly, to do any act or thing which it would be unlawful for such person to do under the provisions of this chapter or any rule or regulation thereunder through or by means of any other person.

(c) Hindering, delaying, or obstructing the making or filing of any document, report, or information. It shall be unlawful for any director or officer of, or any owner of any securities issued by, any issuer required to file any document, report, or information under this chapter or any rule or regulation thereunder without just cause to hinder, delay, or obstruct the making or filing of any such document, report, or information.

(d) Liability for trading in securities while in possession of material nonpublic information. Wherever communicating, or purchasing or selling a security while in possession of, material nonpublic information would violate, or result in liability to any purchaser or seller of the security under any provisions of this chapter, or any rule or regulation thereunder, such conduct in connection with a purchase or sale of a put, call, straddle, option, privilege or security-based swap agreement (as defined in section 206B of the Gramm-Leach-Bliley Act) with respect to such security or with respect to a group or index of securities including such security, shall also violate and result in comparable liability to any purchaser or seller of that security under such provision, rule, or regulation.

15 U.S.C. $\$ 78 t$.

19. SEC Rule 10b-5 is titled, "Employment of Manipulative and Deceptive Devices." It states that: 
trial court consolidated these actions into a single class action suit. ${ }^{20}$ After pre-trial discovery, Dura filed a 12(b)(6) motion to dismiss. ${ }^{21}$ Dura argued that the case should be dismissed because the plaintiffs failed to properly plead that they suffered economic losses as a result of Dura's misrepresentation, i.e.- that the plaintiffs failed to adequately plead loss causation. ${ }^{22}$ The district court granted Dura's motion, reasoning that the plaintiffs failed to plead loss causation because the announcement on the last day of the class period, which coincided with the dip in Dura's stock price, did not mention Dura's Albuterol Spiros device. ${ }^{23}$ The plaintiffs appealed this decision to the Court of Appeals for the Ninth Circuit. ${ }^{24}$ The Ninth Circuit reversed, holding that the plaintiffs adequately pled loss causation by alleging that they purchased artificially overpriced securities. ${ }^{25}$ The defendants petitioned the Supreme Court for a writ of certiorari. ${ }^{26}$

\section{LEGAL BACKGROUND}

\section{A. Causation in a Rule 10b-5 Claim}

In Binder $v$. Gillespie, the Ninth Circuit listed the six elements that must be pled and proven in order to prevail in a private Rule $10 \mathrm{~b}-5$ securities fraud claim. ${ }^{27}$

It shall be unlawful for any person, directly or indirectly, by the use of any means or instrumentality of interstate commerce, or of the mails or of any facility of any national securities exchange,

(a) To employ any device, scheme, or artifice to defraud,

(b) To make any untrue statement of a material fact or to omit to state a material fact necessary in order to make the statements made, in the light of the circumstances under which they were made, not misleading, or

(c) To engage in any act, practice, or course of business which operates or would operate as a fraud or deceit upon any person, in connection with the purchase or sale of any security.

17 C.F.R. $\$ 240.10 \mathrm{~b}-5$ (2007).

20. Broudo, 339 F.3d at 937.

21. Federal Rule of Civil Procedure 12(b)(6) provides that a defendant may submit a motion for immediate dismissal if the plaintiff's complaint fails to plead an affirmative cause of action or sufficient facts under which relief can be granted.

22. Broudo, 339 F.3d at 937. Note that in the original complaint, the plaintiffs also asserted that Dura's representations during the class period about Ceclor $\mathrm{CD}$, an antibiotic, also violated the aforementioned securities laws. Id. However, the trial court dismissed this claim as well because the plaintiffs failed to plead facts that indicated that Dura acted with scienter in making misstatements about Ceclor CD. Id. This issue was pursued on appeal to the Ninth Circuit, which vacated the trial court's findings because the district court had examined each individual allegation in isolation rather than focusing on the totality of the facts alleged. See id. at 940. Interestingly, this issue was not pursued in the second appeal, and thus was not before the Supreme Court in Dura.

23. Id. Note that loss causation has long been thought to be a separate and distinct element of a Rule 10b5 claim, though the Supreme Court until Dura had not endorsed a bifurcated transaction causation-loss causation analysis for 10b-5 claims. See Merritt B. Fox, After Dura: Causation in Fraud-on-the-Market Actions, $31 \mathrm{~J}$. CORP. L. 829, 832 (2006).

24. Broudo, 339 F.3d at 937 .

25. Id. at 941 .

26. Dura Pharms., Inc. v. Broudo, 544 U.S. 336, 340 (2005).

27. 184 F.3d 1059, 1065 (9th Cir. 1999), cert. denied sub nom., Binder v. Wilson, 528 U.S. 1154 (2000). The author would like to conspicuously note that there is no relation between the Thomas Gillespie from Binder $v$. 
Specifically, the court explained that "[a] successful securities fraud action requires proof of a (1) misrepresentation or omission (2) of material fact (3) made with scienter (4) on which the plaintiff justifiably relied (5) that proximately cause[d] the alleged loss." 28 Courts have tended to sub-divide the sixth "causation" element into two pieces, transaction causation and loss causation, since the Second Circuit did so in Schlick v. Penn Dixie Cement Corp. ${ }^{29}$ in $1974 . .^{30}$ Generally speaking, transaction causation refers to facts that prove that the plaintiff relied upon the validity of representations made by the defendant when entering into the securities purchase transaction at issue. ${ }^{31}$ It is somewhat akin to proof of reliance. ${ }^{32}$ Loss causation refers to facts that prove that the plaintiff actually suffered a financial loss as a result of her reliance upon the misrepresentations made by the defendant. ${ }^{33}$ It is more akin to proof of proximate cause. ${ }^{34}$ Circuits have been split as to what factual predicates constitute a showing of loss causation, i.e.- - when is a shareholder plaintiff's financial injury sufficiently definite such that is a redressible injury in a $10 \mathrm{~b}-5$ case.

Prior to Dura, the Ninth Circuit applied the minority view of loss causation. In Knapp v. Ernst \& Whinney, the Ninth Circuit explained that, "[i]n a fraud-on-themarket case, plaintiffs establish loss causation if they have shown that the price on

Gillespie and the author. Thomas J. Gillespie formed Aqua Vie Beverage Corporation (AVBC) in 1991 by purchasing a publicly owned shell corporation and merging it with his Hawaii-based beverage company, KWC, Inc. See id. at 1062 . He later moved this organization to Sun Valley, Idaho, and began producing "lightly flavored," noncarbonated spring water. Id. (quotations omitted). AVBC stock soon began trading publicly on the over-the-counter (OTC) market. Id. In 1994, Albert Binder sued AVBC and Thomas J. Gillespie personally alleging that Mr. Gillespie, while acting in his capacity as CEO of AVBC, violated section 10(b) of the '34 Act and Rule 10b-5. See id. The author, Thomas F. Gillespie III is the Technology Transfer Associate for the J. Craig Venter Institute (JCVI) and is completely unrelated to the Dura litigation.

28. Id.

29. 507 F.2d 374 (2d Cir. 1974).

30. See Binder, 184 F.3d at 1065 (observing that "[t]he causation requirement in Rule $10 \mathrm{~b}-5$ securities fraud cases includes 'both transaction causation, that the violations in question caused the plaintiff to engage in the transaction, and loss causation, that the misrepresentations or omissions caused the harm'" (quoting McGonigle v. Combs, 968 F.2d 810, 820 (9th Cir. 1992))).

31. Id. Please note that in traditional deceit and misrepresentation actions, which are the common law ancestors of Rule 10b-5, there was privity between the defendant and the plaintiff often due to face-to-face dealings, wherein the alleged misrepresentation or deceitful statement was made. See Dura Pharms., 544 U.S. at 344.

32. See Lentell v. Merrill Lynch \& Co., 396 F.3d 161, 172 (2d Cir. 2005) (stating that "[ $\mathrm{t}$ |ransaction causation is akin to reliance, and requires only an allegation that 'but for the claimed misrepresentations or omissions, the plaintiff would not have entered into the detrimental securities transaction'" (quoting Emergent Capital Inv. Mgmt., LLC v. Stonepath Group, Inc., 343 F.3d 189, 197 (2d Cir. 2003))), cert. denied, 546 U.S. 935 (2005).

33. Id.

34. See Devin F. Ryan, Comment, Yet Another Bough on the "Judicial Oak": The Second Circuit Clarifies Inquiry Notice and Its Loss Causation Requirement under the PSLRA in Lentell v. Merrill Lynch \& Co., 79 ST. Joнn's L. Rev. 485, 509 (2005) ("[L]oss causation, the far more subtle stepchild of causation, is arguably analogous to the tort concept of proximate or legal causation."). 
the date of purchase was inflated because of the [defendant's] misrepresentation." ${ }^{35}$ Other circuits, including the Eighth and Second Circuits, also have endorsed this approach. ${ }^{36}$ This view of loss causation presumes that plaintiffs suffer a financial loss at the time of the purchase transaction because they pay more for the security than it is actually worth. ${ }^{37}$ The fact that the loss, at that instant, is purely speculative and has not been realized in dollars and cents is deemed irrelevant. In so doing, the minority view implicitly presumes that securities have some inherent "intrinsic value." ${ }^{38}$ Under this view of loss causation, when a seller makes a misrepresentation that distorts the trading price of a security and changes it from its "intrinsic value," the seller defrauds the purchaser in violation of federal securities laws at that instant. $^{39}$

The majority view of loss causation is different. It requires plaintiffs to prove that they have suffered an actual financial loss in a subsequent sale transaction. The Third, Fourth, Fifth, Sixth, Seventh, and Eleventh Circuits all support some manifestation of this view. ${ }^{40}$ The majority approach does not assume that plaintiffs suf-

35. 90 F.3d 1431, 1438 (9th Cir. 1996) (emphasis added), cert. denied sub nom., Ernst \& Young LLP v. Knapp, 519 U.S. 1112 (1997). This view finds support from several commentators who have opined that the injurious event in a section 10 (b) claim is the purchase transaction itself and that, if there is a subsequent realization of the truth either all at once via a corrective disclosure or via a slow and steady leaking of information, those events are properly understood as evidence of the extent of the injury that was already suffered rather than the injurious events themselves. See Fox, supra note 23, at 832; Marge S. Thorsen et al., Rediscovering the Economics of Loss Causation, 6 J. Bus. \& SEC. L. 93, 99 (2006).

36. See, e.g., Gebhardt v. Conagra Foods, Inc., 335 F.3d 824, 832 (8th Cir. 2003) (holding that it was a sufficient allegation that the "[p]laintiffs were harmed when they paid more for the stock than it was worth"); Suez Equity Investors, L.P. v. Toronto-Dominion Bank, 250 F.3d 87, 97-98 (2d Cir. 2001) (stating that, "Ip]laintiffs may allege transaction and loss causation by averring both that they would not have entered the transaction but for the misrepresentations and that the defendants' misrepresentations induced a disparity between the transaction price and the true 'investment quality' of the securities at the time of transaction"); Gray v. First Winthrop Corp., 82 F.3d 877, 886 (9th Cir. 1996).

37. See Knapp, 90 F.3d at 1438.

38. Indeed, the "intrinsic value" theory has been a staple in conventional securities analysis since 1934. See Burton G. Malkiel, A Random Walk Down Wall Street 29-30 (2003); see also Graham and Dodd's SeCurity ANalysis (Sidney Cottle et al. eds., 5th ed. 1988) (explaining in great detail how to properly compute the intrinsic value of an investment based upon various measurable financial indicators and multipliers).

39. Broudo v. Dura Pharms., Inc., 339 F.3d 933, 938 (9th Cir. 2003).

40. See, e.g., Semerenko v. Cendant Corp., 223 F.3d 165, 185 (3d Cir. 2000) (stating that " [w] here the value of the security does not actually decline as a result of an alleged misrepresentation, it cannot be said that there is in fact an economic loss attributable to that misrepresentation ... [and that i]n the absence of a correction in the market price, the cost of the alleged misrepresentation is still incorporated into the value of the security and may be recovered at any time simply by reselling the security at the inflated price"), cert. denied, 531 U.S. 1149 (2001); Robbins v. Koger Props., Inc., 116 F.3d 1441, 1448 (11th Cir. 1997) (observing that decisions "explicitly require proof of a causal connection between the misrepresentation and the investment's subsequent decline in value"); Bastian v. Petren Res. Corp., 892 F.2d 680, 684-86 (7th Cir. 1990) (ruling that the plaintiffs failed to demonstrate that the investment declined in value because of the materialization of a risk that was undisclosed because of the defendant's fraud), cert. denied, 496 U.S. 906 (1990); Carlton v. Franklin, Nos. 89-2942, 2972, 2974, 1990 WL 116788, at *4-5 (4th Cir. Aug. 2, 1990) (per curiam) (holding that loss causation required the plaintiffs to prove that the defendants' fraud, in some reasonably direct way, touched upon the reason for the investment's decline in value); Campbell v. Shearson/Am. Express Inc., Nos. 85-1703, 1714,1987 WL 44742, at ${ }^{2}$ (6th Cir. Sept. 9, 1987) (finding that the plaintiffs argument failed to make a distinction between reliance and causation and that the plaintiff never demonstrated that the defendant's fraud 


\section{Thomas F. Gillespie III}

fer an economic loss when they purchase securities, even if the price paid is artificially inflated due to a misrepresentation or omission. ${ }^{41}$ Rather, this view requires that plaintiffs prove that they suffered a loss that can be measured after they entered into the securities purchase transaction. In other words, they must prove that the defendant's misrepresentation caused the plaintiffs' purchase price to be artificially high, and that the plaintiffs lost money in some measurable respect as a result. ${ }^{42}$ In so doing, this view at least inferentially rejects the notion that securities have some inherent "intrinsic value." There is some evidence to suggest that Congress may have intended to codify this view of loss causation when it passed the PSLRA in $1995 .^{43}$ The statutory language it used to do so, however, is ambiguous and does not expressly adopt this approach. ${ }^{44}$

\section{B. Pleading Requirements for a Rule 10b-5 Claim}

Prior to Dura, the appropriate pleading standard applicable to each element of a Rule 10b-5 claim was somewhat of an open question. Generally speaking, federal civil actions are governed by the Federal Rules of Civil Procedure, which call for notice pleading. ${ }^{45}$ However, in 1995 Congress passed the PSLRA, which, among other measures, created heightened pleading requirements in federal securities fraud actions under Rule $10 \mathrm{~b}-5 .{ }^{46}$ More specifically, sections $21 \mathrm{D}(\mathrm{b})(1)$ and (2) explicitly created heightened pleading requirements for the misrepresentation and

directly caused a decline in the value of the investment); Huddleston v. Herman \& MacLean, 640 F.2d 534, 549 (5th Cir. 1981), affd in part and rev'd in part on other grounds, 459 U.S. 375 (1983).

41. See Broudo, 339 F.3d at 938.

42. See id.

43. See supra note 8 . Please note that the pleading standards promulgated by the PSLRA were putatively modeled after the Second Circuit's standard, which required more than notice pleading for loss causation at the time the PSLRA was drafted. See S. Rep. No. 104-98, at 7 (1995) (Conf. Rep.), reprinted in 1995 U.S.C.C.A.N. 679,686 (stating that the purpose of the original PSLRA bill was, "[to clarify] the pleading requirements for bringing securities fraud claims by adopting a standard modelled [sic] on that currently applied by the United States Court of Appeals for the Second Circuit, the leading circuit court in [the] arean (emphasis added)); see also, Ryan, supra note 34, at 489 (observing that Second Circuit announced in its Lentell v. Merrill Lynch ob Co. decision that loss causation must be plead to a higher standard than notice pleading, and that the standard to which it must be pled is similar to the one subsequently proscribed by Congress via the PSLRA for scienter and misrepresentation). More specifically, the Second Circuit's Lentell decision, which raised the pleading standard for loss causation, was announced on January 20, 2005. See Lentell v. Merrill Lynch \& Co., 396 F.3d 161 (2d Cir. 2005), cert. denied, 546 U.S. 935 (2005).

44. See 15 U.S.C. $\$ 78 \mathrm{u}-4(\mathrm{~b})(4)(2000)$ (stating that “[i]n any private action arising under this chapter, the plaintiff shall have the burden of proving that the act or omission of the defendant alleged to violate this chapter caused the loss for which the plaintiff seeks to recover damages" (emphasis added)).

45. See FED. R. Civ. P. 8(a)(2) (requiring "a short and plain statement of the claim showing that the pleader is entitled to relief"); see also Conley v. Gibson, 355 U.S. 41, 47 (1957) (stating that "the Federal Rules of Civil Procedure do not require a claimant to set out in detail the facts upon which he bases his claim").

46. See 15 U.S.C. $\$ 78 \mathrm{u}-4(\mathrm{~b})(1)$. In section $21 \mathrm{D}(\mathrm{b})(1)$, the PSLRA states:

Misleading Statements and Omissions.-In any private action arising under this title in which the plaintiff alleges that the defendant-

(A) made an untrue statement of a material fact; or

(B) omitted to state a material fact necessary in order to make the statements made, in the light of the circumstances in which they were made, not misleading; 


\section{Dura Pharmaceuticals, Inc. v. Broudo}

scienter elements of a Rule 10b-5 claim. ${ }^{47}$ Interestingly, the provision in the PSLRA that addressed loss causation did not expressly call for the application of a heightened pleading standard to plaintiffs' loss causation pleadings. ${ }^{48}$ Some have argued that Congress only intended for the misrepresentation and scienter elements to be subject to a heightened pleading requirement, and intended the loss causation element to be pled according to the more traditional notice pleading standard. ${ }^{49}$ Others have argued that the omission was the result of poor drafting, and that reading the PSLRA to add the loss causation element and then simultaneously exclude it from the new pleading standard is illogical and counterproductive in light of the legislation's putative purpose. ${ }^{50}$

\section{THE COURT'S REASONING}

\section{A. The Court's Holding Regarding the Substantive Elements of a Rule 10b-5 Claim}

In Dura Pharmaceuticals, Inc. v. Broudo the Supreme Court reviewed the Ninth Circuit's holding that a plaintiff could properly plead and prove loss causation, "simply by alleging in the complaint and subsequently establishing that 'the price' of the securities 'on the date of purchase was inflated because of the [defendant's] misrepresentation.' "sl The Court held that this view of loss causation was fallacious, stating that the Ninth Circuit's view of what must be pled and proven was incorrect. ${ }^{52}$ However, rather than proffer some affirmative guidance as to what constitutes a showing of loss causation, the Court chose to pursue an addition-bysubtraction approach in its jurisprudence in this area, merely explaining why the Ninth Circuit's approach was incorrect. To that end, the Court pointed to three rationales for its holding. ${ }^{53}$

the complaint shall specify each statement alleged to have been misleading, the reason or reasons why the statement is misleading, and, if an allegation regarding the statement or omission is made on information and belief, the complaint shall state with particularity all facts on which that belief is formed.

Pub. L. No. 104-67, 109 Stat. 737 (1995).

47. See Private Securities Litigation Reform Act $\$ 21 \mathrm{D}(\mathrm{b})(1)-(2)$.

48. See supra note 44 .

49. See Patrick J. Coughlin et al., What's Brewing in Dura v. Broudo? The Plaintiffs' Attorneys Review the Supreme Court's Opinion and Its Imports for Securities Fraud Litigation, 37 Loy. U. CHI. L.J. 1, 9-10 (2005); see also Christopher J. Dutton, Note, Dura Pharmaceuticals, Inc. v. Broudo: Extracting Teeth from Securities Regulation, 33 N. Ky. L. Rev. 153, 178 (2006).

50. See Ryan, supra note 34, at 489 (arguing that the Second Circuit correctly held that a fact-specific inquiry into the causal link between the fraud and the drop in stock price was an indispensable touchstone of pleading a Rule 10b-5 claim because, in doing so, the court was resetting "the benchmark of its loss causation pleading standards to the heightened level originally intended by Congress under the PSLRA" (emphasis added)); see also supra note 8 .

51. Dura Pharms., Inc. v. Broudo, 544 U.S. 336, 338 (2005) (quoting Broudo v. Dura Pharms., Inc., 339 F.3d 933, 938 (9th Cir. 2003)).

52. Id.

53. Id. 
The Court first observed that the Ninth Circuit's view of loss causation was illogical. The Court stated that, "as a matter of pure logic, at the moment the transaction takes place, the plaintiff has suffered no loss; the inflated purchase payment is offset by ownership of a share that at that instant possesses equivalent value." ${ }^{154}$ The most that logic alone permits, reasoned the Court, "is that the higher purchase price will sometimes play a role in bringing about a future loss," though not always. ${ }^{55}$ Thus, the Court rejected the Ninth Circuit's view of loss causation because it conflated the idea that a detriment would sometimes impact a purchaser with the notion that it would always do so.

Next, the Court stated that the uniqueness of the Ninth Circuit's view argued against its validity because of the nature of a private Rule $10 \mathrm{~b}-5$ claim. ${ }^{56}$ The Court explained that a lack of support from other circuits was particularly damning to the Ninth Circuit's approach because a private Rule $10 \mathrm{~b}-5$ claim was a judicially implied cause of action, and thus has its roots in the common law. ${ }^{57}$ More specifically, the Court likened Rule 10b-5 claims to common law deceit and misrepresentation actions, which require proof of actual economic loss in order for a remedy to lie. ${ }^{58}$ The Court observed that in order to recover in such actions, "a plaintiff [must] show not only that had he known the truth he would not have acted but also that he suffered actual economic loss." ${ }^{\text {g9 }}$ Because the Ninth Circuit's approach deviated from the requirements of similar common law claims, the Court opined that it was not surprising that other circuits had rejected the Ninth Circuit's "inflated purchase price" approach.$^{60}$ Furthermore, reasoned the Court, because a Rule $10 \mathrm{~b}-5$ claim had its roots in the common law, the lack of support from other circuits suggested that the Ninth Circuit's approach was incorrect. ${ }^{61}$

Finally, the Court observed that the Ninth Circuit's "inflated purchase price" approach frustrated the purpose of the PSLRA and American securities laws generally. ${ }^{62}$ The Court stated that the goal of the federal securities laws is to, "maintain public confidence in the marketplace," rather than to provide investors with insurance against potential financial losses. ${ }^{63}$ Additionally, the Court observed that the language of the PSLRA emphasizes the requirement that a plaintiff must have suffered an actual financial loss in order to recover. ${ }^{64}$ According to the Court, adopting

\footnotetext{
54. Id. at 342 .

55. Id. at 343 .

56. Id.

57. Id. Essentially, the Court was arguing that where a cause of action is judicially created and has no legislative framework or finite restrictions, the majority view probably is better because that is how traditional common law developed.

58. Id. at 344 .

59. Id. at 343-44 (emphasis added).

60. Id. at 344

61. Id. at 345 .

62. Id. at 346 .

63. Id. at 345 .

64. Id.
} 
the Ninth Circuit's "inflated purchase price" approach would have effectively transformed issuers into insurers of their own securities' future performance and thereby created a windfall for opportunistic plaintiffs who never suffered "actual" economic losses. ${ }^{65}$ Thus, the Court reasoned, the Ninth Circuit's "inflated purchase price" approach was inconsistent with American securities laws and the PSLRA because it would have provided strike suit plaintiffs, ${ }^{66}$ who had not suffered any actual losses, with a windfall recovery, and facilitated their continued abuse of private Rule $10 \mathrm{~b}-5$ class action litigation. ${ }^{67}$

For these reasons, the Supreme Court reversed the Ninth Circuit's decision that loss causation could be proven via the "inflated purchase price" approach ${ }^{68}$ and held that plaintiffs must prove that they have suffered an actual economic loss in order to prove loss causation on the merits. ${ }^{69}$

\section{B. The Court's Holding Regarding the Pleading Standard Applicable to the Loss Causation Element of a Rule 10b-5 Claim}

The Dura Court also addressed the loss causation pleading issue, holding that the plaintiffs' complaint was insufficient as a matter of law because it failed to allege that the plaintiffs had suffered actual economic losses. ${ }^{70}$ In so doing, the Court chose not to articulate any particular standard with respect to the proper pleading standard for plaintiffs' loss causation pleadings, again opting for an addition-bysubtraction approach. ${ }^{11}$ More specifically, the Court stated that it need not reach the issue of whether a higher pleading standard should be required of future plaintiffs' loss causation pleadings within the federal courts because the plaintiffs could not even meet the bare-bones threshold of traditional notice pleading. ${ }^{72}$ Thus, the Court remanded the case. ${ }^{73}$

\section{ANALYSIS}

Though Dura is a step in the right direction, it did not sufficiently clarify what is needed to plead and prove economic loss and loss causation. Part IV of this Note

\section{Id.}

66. Robert W. Hamilton \& Richard A. Booth, Corporation Finance 580 n.2 (3d ed. 2003) ("A strike suit is an action brought by a stockholder (or his or her lawyer) primarily for its nuisance or settlement value.").

67. Dura Pharms., 544 U.S. at 345.

68. Id.

69. Id. at 346 .

70. Id.

71. See id. (stating that in order to survive a 12(b)(6) motion to dismiss pleadings need only provide, "'a short and plain statement of the claim showing that the pleader is entitled to relief.'" (quoting FED. R. CIv. P. 8(a)(2))).

72. The Court stated, "we assume, at least for argument's sake, that neither the Rules nor the securities statutes impose any special further requirement in respect to the pleading of proximate causation or economic loss." Id.

73. Id. at $347-48$. 
has three sections. The first section discusses what the Court's Dura holding accomplishes. The second discusses what issues the Court's holding leaves open, and argues that these items should have been squarely addressed. The third and final section argues that the Court should have held that the out-of-pocket rule is the only appropriate measure of damages in a fraud-on-the-market case. It also argues that plaintiffs should have to plead loss causation with particularity. To that end, it proposes that plaintiffs be encouraged to plead that there was a corrective disclosure price drop; but that, if no such facts can be alleged, they may also allege facts that evince the existence of a legitimate nexus between the defendant's alleged omission or misrepresentation and the out-of-pocket losses/damages of which the plaintiffs complain in order to properly plead loss causation.

A. Dura legitimized the loss causation element of a rule 10b-5 claim, and dismissed the Ninth Circuit's approach to loss causation.

Dura is not a total loss. In Dura, the Supreme Court attempted to dispel the notion that the same set of facts can serve as proof of both transaction causation and loss causation. The Court accomplished this by dismissing the Ninth Circuit's conception of loss causation as illogical. ${ }^{74}$ Prior to Dura, several Circuits and commentators were conceptualizing the inquiry in purely economic terms under the auspice of erring on the side of the shareholder despite the PSLRA's clear aim at tightening the pleading requirements for $10 \mathrm{~b}-5$ cases. ${ }^{75}$ In dismissing the Ninth Circuit's approach, the Court's holding also legitimized the bifurcated approach to pleading and proving causation in private $10 \mathrm{~b}-5$ cases. ${ }^{76} \mathrm{Had}$ the Court sided with the Ninth Circuit, three of the six elements of a Rule 10b-5 claim could have been presumed in fraud-on-the-market cases. ${ }^{77}$ Such a result would almost assuredly have further exacerbated the strike suit phenomenon Congress intended to prevent and may have bankrupted the loss causation element of any proximate causation functionality it might have had. ${ }^{78}$ To the extent that the Court's substantive holding makes it harder for uninjured shareholders to become certified members of a federal securi-

74. See id. at 342 (stating the Ninth Circuit's view that, "at the end of the day plaintiffs need only 'establish,' i.e., prove, that 'the price on the date of purchase was inflated because of the misrepresentation.' . . is wrong ..." (quoting Broudo v. Dura Pharms., Inc., 339 F.3d 933, 938 (9th Cir. 2003))).

75. See supra note 8; see also Elizabeth Chamblee Burch, Reassessing Damages in Securities Fraud Class Actions, 66 MD. L. Rev. 348, 393 (2007) ("Congress passed the PSLRA, in part, to facilitate earlier dismissal of securities class actions that do not plead a prima facie case.").

76. See Fox, supra note 23 , at 842 (observing that the Supreme Court was not the judicial body that developed the bi-furcated causation analysis, and that the Court's Dura holding was its first acknowledgement that such an approach was proper in Rule $10 \mathrm{~b}-5$ cases).

77. See Mackenzie Shea, Comment, Securities Fraud Litigation-Lost in Causation: Investors Not Entitled to Presumption of Loss Causation in Fraud-on-the-Market Cases-Dura Pharmaceuticals, Inc. v. Broudo, 125 S. Ct. 1627 (2005), 11 Suffolk J. Trial \& App. Adv. 255, 261 (2006) (observing that in fraud-on-the-market cases reliance and/or transaction causation is presumed, and if the same facts can prove loss causation and transaction causation as the Ninth Circuit's approach allows, loss causation is essentially presumed as well).

78. See id.; see also supra note 8 . 
ties fraud plaintiff class - the putative purpose of the PSLRA - it is clearly a victory for the securities fraud defense bar, public companies, and the investing public. ${ }^{79}$ Unfortunately, that is about all the credit that can be attributed to Dura. The Court should have done much more. ${ }^{80}$

\section{B. The Court missed an opportunity to provide lower courts with affirmative guidance regarding loss causation and economic loss.}

Though judicial restraint is a useful and important tool in Supreme Court jurisprudence, its utilization in Dura with respect to many of the issues presented was disappointing. Regardless of what the Court may have intended it to do, Dura settled very little. ${ }^{81}$ Among other things, the opinion failed to clarify what constitutes a redressible injury in fraud-on-the-market cases. It did not identify which factual predicates constitute a showing of actual economic loss, or clarify the extent to which plaintiffs must plead loss causation. ${ }^{82}$ This is particularly disappointing because it is unlikely that a better opportunity to clarify these issues will materialize due to the unique orientation of the interested parties in fraud-on-the-market 10b5 cases. ${ }^{83}$ The Court was no doubt aware of these circumstances; they were conspicuously noted in the legislative history of the PSLRA. ${ }^{84}$ As such, the Court should have offered more affirmative guidance with respect to these issues, but it chose not to do so explicitly.

Few commentators were satisfied with the Court's holding in Dura, which is not surprising in light of the plethora of issues the Court's opinion left open. ${ }^{85}$ The Dura Court did not explain what it meant by "actual economic loss," a term used throughout the opinion. ${ }^{86}$ Nor did the Court even mention the out-of-pocket rule for calculating damages in its description of "actual economic loss," leaving many to wonder whether alternative damages theories are available in a fraud-on-the-

79. See Gregory A. Markel et al., Loss Causation after Dura Pharmaceuticals v. Broudo, PLI/CorP., Nov. 2005, at 1291, 1294, (stating that, "it is the author's position that Dura is a helpful decision for those defending securities fraud lawsuits").

80. See Fox, supra note 23, at 842 (observing that Dura leaves open two important questions: (1) what constitutes a showing of actual economic loss, and (2) whether a corrective disclosure is required in order to demonstrate loss causation); see also Burch, supra note 75, at 381 ("Without consensus on how to measure loss, both attorneys and corporate actors lack a defined starting point for estimating financial costs.").

81. See Olazabal, supra note 7, at 379 ("Dura may be just as important for what it did not accomplish as for what little it said about loss causation.").

82. See supra note 80; see also John C. Coffee, Jr., Loss Causation after Dura: Something for Everyone, N.Y.L.J., May 20, 2005, at 5 (arguing that Dura further confuses, rather than clarifies, what is required to plead and prove loss causation).

83. See infra notes $98-103$ and accompanying text.

84. See infra note 106.

85. See, e.g., Coffee, supra note 82; Fox, supra note 23; Larry E. Ribstein, Fraud on a Noisy Market, 10 Lewis \& CLARK L. Rev. 137, 153-55 (2006) (arguing that Dura failed to clarify the application of fraud-on-themarket theory).

86. See Dura Pharms., Inc. v. Broudo, 544 U.S. 336 (2005). 


\section{Thomas F. Gillespie iII}

market cases post-Dura. ${ }^{87}$ After Dura, it is also unclear whether holders of the defendant's securities can join the plaintiff class, i.e. whether there is a sell-to-sue requirement. ${ }^{88}$ The Court also did not clearly explain whether a corrective disclosure price drop is required in fraud-on-the-market cases in order to plead and prove loss causation, or if not, what other types of facts would constitute sufficient proof thereof. ${ }^{89}$ Finally, and perhaps most importantly, the Court offered no af-

87. Indeed, the blanket application of the out-of-pocket damages rule to fraud-on-the-market plaintiffs in section 10 (b) cases had been, until Dura, relatively settled. See Burch, supra note 75, at 359 ("The few opinions available on open-market damages generally limit plaintiffs' recovery to out-of-pocket losses . . .."). But $c f$. Dura Pharms., 544 U.S. at 343-44 (explaining that Rule 10b-5 claims are akin to their common law predecessors deceit and misrepresentation actions, and explaining that courts should apply the same flexible damages principles present in those causes of action to determine whether a Rule 10b-5 claimant has make an appropriate claim for relief). The Court also noted in a parenthetical that, "[t]he same is true in respect to a claim that a share's higher price is lower than it otherwise would have been ...." See id. at 343. Some commentators have suggested that this parenthetical reference is evidence that the Court views this situation, where the price goes up but not as much as the plaintiff thinks it would have but for the defendant's alleged misrepresentation (what I have termed the, "did-not-appreciate-enough theory"), on the same footing as the traditional price drop misrepresentation scenario. See Burch, supra note 75, at 351 n.7. Cf. In re Merrill Lynch Inv. Mgmt. Funds Sec. Litig., 434 F. Supp. 2d 233 (S.D.N.Y. 2006) (finding that holders of the defendant's shelf funds, which appreciated in value, could not demonstrate economic losses based upon a theory that they would have made more money but for the defendant's misrepresentation). Though the Court seemed to be stating that it was not opining on the legitimacy of such an injury, it seems clear that the Court's language did not announce a clear endorsement of the out-of-pocket rule, which would have excluded such a theory. As such, post-Dura there is confusion about the legitimacy of the did-not-appreciate-enough theory and as a consequence the scope of applicability of the out-of-pocket rule. See Dura Pharms., 544 U.S. at 342. This Note argues that the Dura Court should have expressly adopted the out-of-pocket rule for fraud-on-the-market cases, which would have created an explicit sell-to-sue requirement and categorically excluded did-not-appreciate-enough plaintiffs from recovering. See infra Part IV.C.1.

88. See Fox, supra note 23 , at 842 . Some federal courts post-Dura have held that Dura does not create a sell-to-sue obligation on the part of potential plaintiff shareholders. See Ong ex rel. Ong v. Sears, Roebuck \& Co., 459 F. Supp. 2d 729, 743 (N.D. Ill. 2006); In re Royal Dutch/Shell Transp. Sec. Litig., 404 F. Supp. 2d 605 (D.N.J. 2005). While at first blush this might seem strange in light of the language the Court uses in Dura to discuss the proverbial 10b-5 plaintiff's injuries, Dura does not explicitly state that plaintiffs must sell in order to be able to suffer a compensable injury. See Dura Pharms., 544 U.S. at 342 . More specifically, when the Dura Court discussed a hypothetical plaintiff s actual economic losses it did so in terms of "sales" and subsequent sale transactions, but did not expressly hold that this was the exclusive vehicle through which actual economic losses could be shown. Id. Subsequent courts have taken note of this disparity, and held that shareholders who hold the defendant's stock, and thus never suffer a loss from an income tax "dollars and cents" perspective still can join the Rule 10b-5 class. See In re Bridgestone Sec. Litig., 430 F. Supp. 2d 728, 738 (M.D. Tenn. 2006) (observing that the only case that read Dura to hold that there was a sell-to-sue requirement, In re Royal Dutch/Shell Transp. Sec. Litig., 380 F. Supp. 2d 509, 557 (D.N.J. 2005), rev'd, 404 F. Supp. 2d 605 (D.N.J. 2005), was subsequently overturned and is no longer good law).

89. See Nursing Home Pension Fund v. Oracle Corp., No. C01-00988 MJJ, 2006 U.S. Dist. LEXIS 94470, at * 35 (N.D. Cal. Dec. 20, 2006) ("At most, what can be inferred ... is that identifying a 'corrective disclosure' is one way in which a 10 (b) plaintiff can demonstrate loss causation. Dura does not, however, state that this is the only way...."); see also Fox, supra note 23, at 842; Olazabal, supra note 7, 379-80 ("[W] hile it recognized the possibility of a corrective disclosure, the [Dura] opinion cannot properly be read to require such a prerequisite to recovery in fraud-on-the-market suits."); Thorsen et al., supra note 35, at 118 ("The argument that loss causation must be demonstrated in every case by a 'corrective disclosure' of 'the Truth' couples the [Dura] Court's illustration of why purchase time inflation does not necessarily always cause loss ... with the [C]ourt's comment about the 'truth' coming out and facts becoming known."). But cf. In re Veeco Instruments, Inc., Sec. Litig., 235 F.R.D. 220 (S.D.N.Y. 2006) (holding that Dura requires the plaintiff to allege that there was a corrective disclosure that can be contemporaneously linked to a drop in the defendant's stock price, and that 
firmative guidance as to the proper pleading standard for loss causation..$^{90}$ Each of these issues was presented in Dura, and ripe for judicial disposition. ${ }^{91}$ But the Court chose not to squarely address them. ${ }^{92}$

These holes in the Court's holding could normally be excused as prudent omissions in the spirit of judicial restraint. This justification is insufficient in this case, however, because of the unique nature of Rule $10 \mathrm{~b}-5$ cases and the limited factual and procedural histories that typically attach to them on appeal. More specifically, because so few, if any, Rule 10b-5 cases go to trial, and because the pleadings stage of the litigation is so important to protecting innocent defendants from strike suits, as noted in the PSLRA's legislative history, the Supreme Court accomplished very little by leaving the most important issues in Dura for another day. ${ }^{93}$

Prior to the passage of the PSLRA, opportunistic, "career" plaintiffs and their counsel manipulated the federal securities fraud litigation system to extract large sums of money from various public companies. ${ }^{94}$ In many instances, these corpo-

there were no intervening causes of that drop in order to survive a 12(b)(6) motion to dismiss in a fraud-onthe-market Rule 10b-5 case); Ribstein, supra note 85 , at 161 (observing that if a corrective disclosure is required, as Dura suggests, then noisy markets would not be a problem).

90. See Dura Pharms., 544 U.S. at 346 (“[W]e assume, at least for argument's sake, that neither the Rules nor the securities statutes impose any special further requirement in respect to the pleading of proximate causation or economic loss."); see also In re Initial Pub. Offering Sec. Litig., 399 F. Supp. 2d 261, 266 n.23 (S.D.N.Y. 2005) ("Dura itself does not define a pleading standard for loss causation; rather, it simply rejects the Ninth Circuit's standard as overly permissive."), affd, Tenney v. Credit Suisse First Boston Corp., Nos. 05-3430CV, 05-4759-CV, 05-4760-CV, 2006 WL 1423785 (2d Cir. May 19, 2006), cert. denied, Liu v. Credit Suisse First Boston Corp., 127 S. Ct. 733 (2006). See generally 15 U.S.C. $\$ 78 \mathrm{u}-4$ (b)(4) (2000) (announcing that loss causation must be pled, but offering no guidance regarding the standard to which it must be pled, stating "in any private action arising under this chapter, the plaintiff shall have the burden of proving that the act or omission of the defendant alleged to violate this chapter caused the loss for which the plaintiff seeks to recover damages" (emphasis added)).

91. See Dura Pharms., 544 U.S. at 345-48. Indeed, Dura was a typical fraud-on-the-market, Rule 10b-5 class action suit, and included a corrective disclosure price drop. Id. at 339. On the last day of the class period, Dura's stock price dropped 47 percent. Id. This was the same day that Dura announced that it did not anticipate hitting its year-end revenue targets due to slower then expected sales of Ceclor $\mathrm{CD}$. Id.

92. See generally id.

93. Indeed, when one considers the great amount of trouble that federal trial courts have had in trying to promulgate a workable standard for these issues, the Court's decision to abstain from opining on them seems even more disappointing. See infra note 99.

94. See H.R. Rep. No. 104-369, at 31 (1995) (Conf. Rep.), reprinted in 1995 U.S.C.C.A.N. 730 (stating that the purpose of the PSLRA is to "return the securities litigation system to [the] high standard" it once exhibited before it was overrun by abusive professional plaintiffs' practices); see also Tellabs, Inc. v. Makor Issues \& Rights, Ltd., 127 S. Ct. 2499, 2504 (2007) (observing that, "[p]rivate securities fraud actions, . . if not adequately contained, can be employed abusively to impose substantial costs on companies and individuals whose conduct conforms to the law"); Merrill Lynch, Pierce, Fenner \& Smith, Inc. v. Dabit, 547 U.S. 71, 81 (2006) (observing the same); Lentell v. Merrill Lynch \& Co., 396 F.3d 161, 171 (2d Cir. 2005) (stating that, "the congressional intent of the PSLRA [was] 'to deter strike suits wherein opportunistic private plaintiffs file securities fraud claims of dubious merit in order to exact large settlement recoveries'" (quoting Novak v. Kasaks, 216 F.3d 300, 306 (2d Cir. 2000))), cert. denied, 546 U.S. 935 (2005); John W. Avery, Securities Litigation Reform: The Long and Winding Road to the Private Securities Litigation Reform Act of 1995, 51 Bus. LAw. 335, 336 (1996) (observing that the original concern of Congress in passing the PSLRA was the "explosion of meritless securities lawsuits, particularly class actions, filed solely for their settlement value"). 
rate targets were not guilty of any wrongdoing. ${ }^{95}$ Congress passed the PSLRA in 1995 in an effort to bring these abusive practices to an end. ${ }^{96}$ Unfortunately, because of the realities of securities fraud litigation practice, the reforms set out by the Act did not create much change. ${ }^{97}$

Several circumstances, somewhat unique to federal securities fraud litigation practice, operate together to make the pre-trial stage of the litigation the most important in the dispute. Specifically, fraud-on-the-market securities fraud cases are almost uniformly pursued as class actions. ${ }^{98}$ Additionally, the cases rarely go to trial because corporate defendants, guilty or not, cannot afford to take the risk that they might lose the case and face a large damage award. ${ }^{99}$ Such a potential financial shortfall is especially damning for public companies because the financial markets demand earnings growth every quarter. ${ }^{100}$ Indeed, even when awards are later set aside or overturned, the corporate defendant's share price often has already been depleted such that it cannot be fully recouped. ${ }^{101}$ In light of this reality, it is not surprising that few corporate managers, who have a fiduciary duty to maximize shareholder value and preserve their employer's share price, are willing to roll the dice and hope that their corporations are exonerated at trial. ${ }^{102}$ Plaintiffs counsel are all too aware of this reality. They know that if they can survive a pre-trial dismissal, the public company defendant will almost assuredly, as a business decision, settle for a significant sum regardless of the strength of the plaintiffs' underly-

95. See Richard M. Phillips \& Gilbert C. Miller, The Private Securities Litigation Reform Act of 1995: Rebalancing Litigation Risk and Rewards for Class Action Plaintiffs, Defendants, and Lawyers, 51 Bus. LAw. 1009, 1010 (1996).

96. See supra note 94 .

97. See infra note 108 .

98. See Phillips \& Miller, supra note 95, at 1015; see also John C. Coffee Jr., Causation by Presumption? Why the Supreme Court Should Reject Phantom Losses and Reverse Broudo, 60 Bus. Law 533, 534 (2005).

99. See Cent. Bank of Denver, N. Am. v. First Interstate Bank of Denver, N.A., 511 U.S. 164, 189 (1994) (observing that plaintiffs in such cases have found that defendants can often be compelled, "as a business judgment, to abandon substantial defenses and to pay settlements in order to avoid the expense and risk of going to trial"); Blue Chip Stamps v. Manor Drug Stores, 421 U.S. 723, $739-40$ (1975) ("[E]ven a complaint which by objective standards may have very little chance of success at trial has a settlement value to the plaintiff out of any proportion to its prospect of success at trial ... ."); see also Burch, supra note 75, at 382-83 ("[M]ost private securities class actions end in confidential settlement $[s] \ldots$ most cases never reach a jury . ..."); Thorsen et al., supra note 35, at 113 (observing that few if any cases ever make it to trial).

100. See Justin Fox \& Rajiv Rao, Learn to Play the Earnings Game (and Wall Street Will Love You), ForTUNE, Mar. 31, 1997, at 76-80 (“'T]he price of missing a quarter has risen sharply . . 'missing by a penny' now implies the height of corporate boneheadedness - that is, if you couldn't find that extra penny to keep Wall Street happy, then your company must really be in trouble, and since missing by a penny is already going to send your stock plummeting, you're better off missing by a dime or two and saving those earnings for the next quarter.").

101. See Burch, supra note 75 , at 384 ("[T]he mere filing of the suit typically causes a drop in a company's stock price.").

102. See S. ReP. No. 104-98, at 7 (1995) (Conf. Rep.), reprinted in 1995 U.S.C.C.A.N. 679, 686 ("[I]f a defendant cannot win an early dismissal of the case, 'the economics of litigation may dictate a settlement even if the defendant is relatively confident that it would prevail at trial" (quoting Securities Litigation Reform: Hearing Before the Subcomm. on Telecomm. and Fin. of the H. Comm. on Energy and Commerce, 103d Cong. 36 (1994))). 
ing claims. ${ }^{103}$ Accordingly, the rejection of a defendant's 12(b)(6) motion to dismiss typically signals the end of the true litigious phase of a suit and the beginning of serious settlement negotiations between the parties, regardless of the merits of the plaintiffs' underlying claims. ${ }^{104}$

The 104th Congress took steps to strengthen the pleading requirements for Rule $10 \mathrm{~b}-5$ cases in an effort to facilitate the dismissal of meritless suits at the earliest possible stage of the litigation. ${ }^{105}$ Via the PSLRA, Congress commanded that scienter and misrepresentation be pled with particularity. ${ }^{106}$ It also stated that $10 \mathrm{~b}-5$ plaintiffs must show proof of economic loss. ${ }^{107}$ Unfortunately, these reforms did not turn out to be the magic bullet that Congress presumably envisioned. ${ }^{108}$ Congress' efforts, though a step in the right direction, were not enough to effectuate the full change then contemplated. ${ }^{109}$ More specifically, the PSLRA did not do enough

103. See id. at 6, reprinted in 1995 U.S.C.C.A.N. 679, at 685 ("[U]nder the current system, the initiative for filing 10b-5 suits comes almost entirely from the lawyers, not from genuine investors.").

104. See supra note 102 .

105. See supra notes 8,94 .

106. See 15 U.S.C. $\$ 78 \mathrm{u}-4(\mathrm{~b})(1)-(2)(2000)$.

107. Id. $\$ 78 \mathrm{u}-4(\mathrm{~b})(4)$ (stating that "in any private action arising under this chapter, the plaintiff shall have the burden of proving that the act or omission of the defendant alleged to violate this chapter caused the loss for which the plaintiff seeks to recover damages").

108. See Joseph A. Grundfest \& Michael A. Perino, Securities Litigation Reform: The First Year's Experience, SEC. Reg. INST. (29TH ANN.), Nov. 1997, at 955, 958 (observing that prior to the passage of the PSLRA the rate of federal securities fraud class action suits was approximately 176 defendant issuers per year, while after the Act was passed that rate had changed to approximately 143-163 defendant issuers per year, and concluding that the PSLRA did not materially impact the number if securities fraud class action lawsuits filed). Indeed, Congress itself admitted that the PSLRA fell short of accomplishing its goals when it discussed the passage of the Securities Litigation Uniform Standards Act of 1998 (SLUSA). See 144 ConG. Rec. S4778 (daily ed. May 13, 1998) ("The Congress finds that-(1) the Private Securities Litigation Reform Act of 1995 sought to prevent abuses in private securities fraud lawsuits; (2) since enactment of that legislation, considerable evidence has been presented to Congress that a number of securities class action lawsuits have shifted from Federal to State courts; (3) this shift has prevented that Act from fully achieving its objectives ... ."); see also 144 Cong. REC. S4781 (statement of Sen. D'Amato) ("So here the President of the United States and the SEC and his Commissioner are saying you are . . closing a loophole that has been used by those who rush to the courts to bring suits because they are looking to enrich themselves, not to protect the little guy or the small investors."). Moreover, during the passage of the PSLRA, senators Gramm, Mack, Faircloth, Bennett, and Frist wanted to make the pleading standards proscribed by the Act stricter and more explicit, but were unable to carry a vote for reconsideration to that end. See S. Rep. No. 104-98, at 33 (1995) (Conf. Rep.), reprinted in 1995 U.S.C.C.A.N. 679, 711 ("[W] hile the bill provides significant incremental relief from abusive securities lawsuits, the costs of these lawsuits are so high that stronger reform is needed.").

109. See supra note 94. Post-Dura, the Court has taken note of the importance of explicitly explaining what is necessary to meet special pleading standards that are tied to judicially implied causes of action. Most recently, in Bell Atlantic Corp. v. Twombly, the Court quoted Dura, observing that its primary objective in applying various pleading standards in such cases is to weed-out those plaintiffs who have, "'a largely groundless claim" "and prevent them from "tak[ing] up the time of a number of other people, with the right to do so representing an in terrorem increment of the settlement value." $127 \mathrm{~S}$. Ct. 1955, 1959 (2007) (quoting Dura Pharms., Inc. v. Broudo, 544 U.S. 336. 347 (2005)). Interestingly, there are substantial parallels between Bell Atlantic Labs. and Dura. For one thing, the chances of an in terrorem use of the judicial system in each case was very high because both were large class action lawsuits. See id. at 1955; Dura Pharms., 544 U.S. at 336. Moreover, in both cases, the plaintiffs' underlying claims derived from judicially implied private causes of action, which were inferred from broader federal statutes aimed at regulating questionable corporate behavior. See Twombly, 127 S. Ct. at 1964; Dura Pharms.; 544 U.S. at 341; see also 15 U.S.C.A. $\$ \$ 1,78$ j (2007). Despite these 


\section{Thomas F. Gillespie ili}

to tighten the criteria for proceeding beyond the pleadings stage of Rule $10 \mathrm{~b}-5$ cases such that legitimate claims proceeded to trial, but meritless claims did not. ${ }^{110}$

It is against this backdrop that the Supreme Court's Dura decision should be judged. When viewed in this light, it is clear that Dura did not tighten 10b-5 pleading requirements enough to effectuate the intentions of the 104th Congress. It failed to place the bite of its holding at the fulcrum of most 10b-5 disputes. This failing is particularly disappointing because Dura was a prototypical $10 \mathrm{~b}-5$ case. Indeed, it is very unlikely that the Court will have an opportunity to review a more developed case than the one presented in Dura because of the aforementioned orientation of the parties in the suit." Moreover, in offering no guidance with respect to what factual predicates constitute a showing of actual economic losses, the Court essentially exchanged an old non-descript loss causation standard for a new one. ${ }^{112}$

\section{The Court should have provided more guidance with respect to what must be pled and proven in fraud-on-the-market Rule 10b-5 cases.}

The Dura Court should have provided lower courts with more affirmative guidance regarding economic loss and loss causation. Specifically, the Court should have held that the out-of-pocket rule is the exclusive vehicle through which plaintiffs can establish actual economic losses in fraud-on-the-market cases. Additionally, the Court should have held that plaintiffs must plead loss causation with particularity. To that end, the Court should have held that pleading the existence of a corrective disclosure price drop is the preferred vehicle for demonstrating loss causation, but if plaintiffs cannot so plead, they have the option to plead other facts that evince the existence of a legitimate nexus between the alleged out-of-pocket losses and the defendant's alleged bad action(s). Such a holding would have been consistent with past precedent and the express language and legislative history of the PSLRA. Moreover, it would have empowered defendants to rebalance the $10 \mathrm{~b}-5$ litigation playing field by making it harder for strike suit plaintiffs and their counsel to proceed with frivolous claims beyond the pleadings stage of the litigation, while still allowing room for legitimate claims. The remainder of this Note will address each of these two proposals in turn.

similarities, the Court did not do in Dura what it did in Bell Atlantic Labs. Indeed, in Dura, unlike in Bell Atlantic Labs., the Court did not squarely address the pleadings issue that was presented, which was arguably the most important issue presented in the case.

110. See supra note 108 .

111. More specifically, in almost all Rule $10 \mathrm{~b}-5$ cases, either the defendant's $12(\mathrm{~b})(6)$ motion is granted and the case is dismissed or it is not and the defendant settles. The Supreme Court must have been aware of this reality because the stated purpose of the PSLRA is to utilize the pleadings stage of $10 \mathrm{~b}-5$ litigation to weed out strike suits. See supra notes 8, 103.

112. See Fox, supra note 23, at 831 ("The Supreme Court's grant of certiorari . . . came against the backdrop of years of highly confusing lower court decisions concerning what a plaintiff needs to show to establish causation in a fraud-on-the-market suit."). 


\section{Dura Pharmaceuticals, Inc. V. Broudo}

1. In its discussion of the substantive issue of loss causation, the Dura Court should have held that the out-of-pocket rule is the only appropriate measure for damages in fraud-on-the-market cases.

The Dura Court should have held that the out-of-pocket rule ${ }^{113}$ is the exclusive vehicle through which plaintiffs can establish damages and/or actual economic losses. Though Dura was not a case about damages, the analysis of a plaintiffs' proof of a sufficient nexus between the defendant's alleged wrongdoing and their alleged damages/losses, i.e. loss causation, necessarily depends upon how one conceptualizes damages/losses. ${ }^{114}$ To that end, and as a matter of first principles, the universe of potential damages theories available in a Rule 10b-5 case should be no broader than those available in its common law predecessors, the actions of deceit and misrepresentation. ${ }^{115}$ Generally speaking, the remedies available in those actions were rescission, benefit-of-the-bargain rule, out-of-pocket rule, and disgorgement. ${ }^{116}$ From this somewhat broad universe of possible damages theories, it is prudent to eliminate those that are nonsensical in light of the orientation of the parties in an open-market Rule 10b-5 case. As such, the benefit-of-the-bargain rule, disgorgement, and rescission should be removed from consideration because these three theories are based, at least implicitly, on the existence of privity between the parties, which is not the case in an open-market Rule 10b-5 case. This leaves only the out-of-pocket rule.

The Court should have explicitly held that the out-of-pocket rule is the only acceptable theory for assessing damages in an open-market Rule 10b-5 claim rather than merely hinting that this was the case. ${ }^{117}$ Such a pronouncement would have been consistent with precedent ${ }^{118}$ and the language of the PSLRA. ${ }^{119}$ Moreover, conceptualizing economic loss in this way enables the loss causation element, which is fundamentally related to economic loss, to have the proximate cause functionality

113. The out-of-pocket rule allows plaintiffs to recover only the amount of damages that they lose out-ofpocket, i.e.- the amount that they overpaid for a given security or asset. It does not embrace recoveries for an injury where a plaintiff claims he could have sold an asset for more consideration but for the defendant's bad action, which is notably much more speculative and difficult to prove. See generally Burch, supra note 75 .

114. See Olazabal, supra note 7 , at 358 ("Though courts and commentators alike have pointed out what may be obvious to some- that loss causation and damages are different elements of [a Rule 10b-5] claim-there is no denying that they are fundamentally interrelated." (citations omitted)); see also Thorsen et al., supra note 35, at 113 (arguing that it is clear that the loss causation inquiry is shaped by how one defines actual economic loss).

115. See Dura Pharms., Inc. v. Broudo, 544 U.S. 336, 343 (2005) (observing that Rule 10b-5 claims are the modern version of the common law claims of deceit and misrepresentation).

116. See Burch, supra note 75 , at 361 .

117. See Dura Pharms., 544 U.S. at 343.

118. The few courts that have fully adjudicated an open-market Rule $10 \mathrm{~b}-5$ claim have applied the out-ofpocket rule of damages. See Burch, supra note 75, at 359 ("The few opinions available on open-market damages generally limit plaintiffs' recovery to out-of-pocket losses . . . . ${ }^{n}$ ).

119. See id. at $356-57$ (observing that the 90 -day look-back period damages cap proscribed by the PSLRA is an out-of-pocket measure of damages). See generally 15 U.S.C. $\$ 78 \mathrm{u}-4(e)(1)(2000)$. 


\section{Thomas F. Gillespie III}

that it is putatively intended to have. ${ }^{120}$ It limits the scope of the potential plaintiffs' pool to a narrower group than those with merely but for or hypothetical losses, while allowing those with legitimate injuries to proceed.

The Dura Court came close to adopting the out-of-pocket rule as the exclusive theory for damages/losses in open-market 10b-5 cases, but did not do so expressly. ${ }^{121}$ In so doing, the Court allowed confusion to linger about whether there is a sell-to-sue requirement, and whether plaintiffs can proceed under the theory that their investment would have appreciated to a greater extent but for the defendant's wrongdoing (the "did-not-appreciate-enough theory"). ${ }^{122}$ The Court should not have left these important issues unresolved. It should have expressly stated that the out-of-pocket rule is the exclusive theory through which fraud-on-the-market plaintiffs can establish actual economic losses. Such a holding would have been consistent with the aims of the PSLRA, which was to make it more difficult for plaintiffs to bring strike suits and cut down on the number of plaintiffs in a hypothetical Rule 10b-5 class at the earliest possible stage in the litigation. ${ }^{123}$ Under the proposed holding, plaintiffs with legitimate face-to-face injuries could still utilize damages theories that make sense in those circumstances, while those who utilize the fraud-on-the-market theory to obtain presumptions of reliance, reasonable reliance, and transaction causation, would need to show that they had real damages/ losses in order to do so. ${ }^{124}$ This would arguably have been the most efficient com-

120. See Burch, supra note 75, at 363-70 (arguing that irrespective of what Dura holds, limiting the plaintiffs' potential recovery to their out-of-pocket damages in Rule 10b-5 actions is the only theory that makes sense when the traditional deceit and misrepresentation frameworks are strained to accommodate a fraud-onthe-market presumption); see also David S. Escoffery, A Winning Approach to Loss Causation Under Rule 10b-5 in Light of the Private Securities Litigation Reform Act of 1995 ("PSLRA"), 68 Fordham L. Rev. 1781, 1790-92 (2000) (observing that, even in traditional face-to-face $10(b)(5)$ actions, courts generally only apply the out-ofpocket rule or, in rare cases, rescission damages).

121. In Dura, the Court renounced the idea that defendants must act as insurers of a plaintiffs' downside risk, presumably precluding the application of a recessionary damages theory since rescission in some cases would return to the plaintiffs losses attributable to investment risk in addition to those losses that could be linked to the defendants' bad action(s). See Burch, supra note 75, at 366-67 ("Requiring the defendant to bear the risk of market decline distinguishes rescissory damages \{awarded in common law deceit and misrepresentation actions] from out-of-pocket damages, which seek to isolate the price due to fraud and permit recovery only for that difference."). In so doing, the Court at least implicitly adopted a policy of applying the out-ofpocket rule exclusively in open-market actions. However, there is also dicta within Dura that suggests the contrary. In a parenthetical, the Dura Court suggested that plaintiffs who pursue recovery under a did-notappreciate-enough theory may be able to recover. See Dura Pharms., 544 U.S. at 343 . Such a recovery would not be possible under the out-of-pocket rule. These contradictory assertions within Dura have caused subsequent confusion about whether the out-of-pocket measure of damages should be universally applied in openmarket $10 \mathrm{~b}-5$ cases.

122. See supra notes 87,88 .

123. See supra notes $8,43,94,102$.

124. This is not an overly burdensome requirement. If almost half of the elements of a Rule $10 \mathrm{~b}-5$ case are going to be presumed under the theory that it would be impractical to require plaintiffs to individually prove that they relied upon the validity of the market, or that their reliance was reasonable, or to prove transaction causation (i.e. if most cases are going to be pursued as they have been to date under a fraud-on-the-market theory), it is not unreasonable to require that the remaining elements be pled and proven in such a way that it is clear that the plaintiffs have suffered real, tangible losses, i.e. scrutinizing those elements that remain a little 
promise between the two competing interests facing the Court. ${ }^{125}$ Unfortunately, the Court did not explicitly hold this and left the door open for plaintiffs' counsel to continue to artificially inflate their classes with holders of the defendant's stock and other parties with illusory or hypothetical losses to the detriment of issuers and the investing public. ${ }^{126}$

\section{The Dura Court should have held that loss causation must be pled with particularity.}

It is unfortunate that the Dura Court chose to analyze the sufficiency of the plaintiffs' loss causation pleadings according to a notice pleading standard. ${ }^{127}$ Instead, the Court should have held that the heightened pleading standard described in the PSLRA applies to the loss causation element of a Rule 10b-5 claim. More specifically, the Court should have held that loss causation must be pled with particularity: that a corrective disclosure price drop is the preferred vehicle through which to establish loss causation, but if no such facts exist, a plaintiff also can plead loss causation by presenting facts that evince the existence of a legitimate nexus between the plaintiffs' alleged out-of-pocket losses and the defendant's misrepresentation/omission. Such a holding would have fixed a loophole in the PSLRA in a fashion consistent with its legislative history. Moreover, it would have struck the appropriate balance between the competing interests at play in a Rule 10b-5 case,

more harshly because of the fact that the plaintiffs are being given the benefit of the doubt via a presumption in so many other areas. If this proposition has merit, and I believe that it does, then the loss causation element, which necessarily subsumes the issue of damages/actual economic loss to a necessary and certain extent, is the best place for this added scrutiny to manifest because the loss causation element is supposed to have a meritsbased filtering functionality similar to that of proximate cause in traditional tort actions.

125. Those two interests are (1) the right of defendants, who have done no wrong, to have confidence that they will be able to dispel a frivolous suit in an efficient and relatively inexpensive way, and (2) the right of legitimate plaintiffs who are injured by corporate wrongdoing to proceed to trial. Obviously, the rights of the former argue in favor of an absolute tightening of the pleading requirements in a Rule $10 \mathrm{~b}-5$ case, while the rights of the latter argue against such a constriction.

126. This argument also finds support in the proposition that the fraud-on-the-market theory is not universally true. See Ribstein, supra note 85 , at 139 (" $[\mathrm{T}]$ he market's potentially irrational response to information raises doubts about the scope of liability for incomplete disclosure, and specifically about the fraud-on-themarket (FOM) theory, especially in light of the Supreme Court's recent opinion in Dura ...."). I do not at this time advocate for a revocation of the theory via a renouncement of Basic v. Levinson, 485 U.S. 224 (1988). However, if it is true that the fraud-on-the-market theory is not universally true and sometimes inaccurate because of biases inherent in the way humans interpret financial data and perceive risk, then plaintiffs and their counsel are receiving the benefit of a presumption that is invalid in some instances. If that is true, it seems logical that the rules regarding those elements that are not presumed should be crafted such that they have the effect of separating legitimate claims from illegitimate ones, if for no other reason than to place a check into the system to disallow plaintiffs from proceeding in an action where there is no basis in fact for liability.

127. In point of fact, the Court side-stepped the question by pointing out that it need not reach the question of whether or not the PSLRA imposed a heightened pleading requirement with respect to loss causation in a Rule $10 \mathrm{~b}-5$ case because it could assume arguendo that the notice pleadings standard of Federal Rule of Civil Procedure 8(a)(2) applied. After all, the plaintiffs' complaint could not even satisfy that low standard. See Dura Pharms. v. Broudo, 544 U.S. 336, 346 (2005). 
and equipped defendants with a legitimate weapon to thwart attacks from strike suit plaintiffs and their counsel.

As described in Part IV.B, the circumstances of most Rule 10b-5 suits make the pleadings stage of the litigation the real battleground for the litigants. ${ }^{128}$ The PSLRA took conspicuous note of this reality and was intended to, among other things, adjust the pleading standards in Rule $10 \mathrm{~b}-5$ cases so that frivolous claims were easily dismissed, but legitimate ones proceeded. ${ }^{129}$ Post-PSLRA, it has become clear that the Act has not had the desired effect on strike suit filings, primarily because it did not do enough to eliminate strike suit plaintiffs at a relevant stage of the litigation process. ${ }^{130}$ The Dura Court was aware of all of these developments. ${ }^{131}$ It was well positioned to address the loss causation pleadings loophole created by the PSLRA, but it did not. ${ }^{132}$

The express language of the PSLRA does not clearly apply a heightened pleading standard or a notice pleading standard to the loss causation element of a Rule 10b5 claim. ${ }^{133}$ The Court should have filled this gap in the law. ${ }^{134}$ More precisely, the Court should have examined the loss causation pleadings issue in light of the underlying purpose of the PSLRA, noted that the PSLRA was incomplete and impre-

128. See generally supra Part IV.B.

129. See supra notes 8,43 .

130. See supra note 108 .

131. Indeed, the Court has been aware of the strike suit problem since its pronouncement in Blue Chip Stamps v. Manor Drug Store, 421 U.S. 723 (1975), where the Court observed that "even a complaint which by objective standards may have very little chance of success at trial has a settlement value to the plaintiff out of any proportion to its prospect of success at trial." Id. at 740; see also Dura Pharms., 544 U.S. at 346 (observing that one of the purposes of the PSLRA was to restore public confidence in the American securities markets).

132. See In re Initial Pub. Offering Sec. Litig., 399 F. Supp. 2d 261, 266 n.23 (S.D.N.Y. 2005) ("Dura itself does not define a pleading standard for loss causation; rather, it simply rejects the Ninth Circuit's standard as overly permissive."), aff $d$, Tenney v. Credit Suisse First Boston Corp., Nos. 05-3430-CV, 05-4759-CV, 05-4760CV (2d Cir. May 19, 2006), cert. denied, Liu v. Credit Suisse First Boston Corp., 127 S. Ct. 733 (2006); see also 15 U.S.C. $\$ 78 \mathrm{u}-4(\mathrm{~b})(4)(2000)$ (announcing that loss causation must be pled but offering no guidance regarding the standard to which it must be pled, stating "[i]n any private action arising under this title, the plaintiff shall have the burden of proving that the act or omission of the defendant alleged to violate this title caused the loss for which the plaintiff seeks to recover damages" (emphasis added)).

133. 15 U.S.C. $\$ 78 \mathrm{u}-4(\mathrm{~b})(4)$.

134. While an argument could be made that Dura is silent as to the proper pleading standard for loss causation pleadings, the Court's reluctant application of a notice pleading standard has been a stumbling block for subsequent defendants who sought to defend themselves by moving to dismiss plaintiffs' claims on loss causation grounds. See In re CMS Energy Sec. Litig., 403 F. Supp. 2d 625, 630 (E.D. Mich. 2005) (holding that " $[t]$ he Supreme Court's opinion in Dura clearly explains that it does not modify the pleading requirements of Fed. R. Civ. P. 8(a)(2), which merely requires a plaintiff to provide 'a short and plain statement of the claim showing that the pleader is entitled to relief'"); see also Ong. ex rel. Ong. v. Sears, Roebuck \& Co., 459 F. Supp. 2d 729, 742 (N.D. Ill. 2006); Brumbaugh v. Wave Sys. Corp., 416 F. Supp. 2d 239, 256 (D. Mass. 2006); CompuDyne Corp. v. Shane, 453 F. Supp. 2d 807, 827 (S.D.N.Y. 2006); Ryan v. Flowserve Corp., 444 F. Supp. $2 d 718,725$ (N.D. Tex. 2006) (explaining that, in its view, Dura holds that loss causation pleadings must only be pled to a notice pleading or 8(a)(2) standard); In re Retek Inc. Sec., No. CIV 02-4209(JRT/SRN), 2005 WL 3059566, at *3 (D. Minn. Oct. 20, 2005); In re Unumprovident Corp. Sec. Litig., 396 F. Supp. 2d 858, 899 (E.D. Tenn. 2005). 
cisely drafted as evinced by the swift subsequent passage of the SLUSA in $1998,{ }^{135}$ and filled the gap left by the PSLRA in a way that furthered its intended purpose. The Court could have held that the PSLRA implicitly requires that loss causation be plead with particularity just like scienter and misrepresentation. ${ }^{136}$

Such an action by the Court would have been appropriate in Dura. Indeed, such an action is precisely the type of gap-filling quasi-legislative roll that the framers intended the Supreme Court to have. ${ }^{137}$ Even the most conservative jurists agree that the Supreme Court must, at the very least, look at the problem that a piece of legislation purports to address and construe ambiguous language within that statute in the way that furthers that purpose most effectively. ${ }^{138}$ Indeed, the stage was set in Dura for a meaningful loss causation pleadings pronouncement to be given, but the Court chose not to do so. ${ }^{139}$

Not only should the Court have held that loss causation must be pled with particularity, it should have held that the preferred vehicle for so pleading it is via a corrective disclosure price drop allegation, with the caveat that plaintiffs also can allege facts that evince the existence of a legitimate nexus between the defendant's alleged omission/misrepresentation and the plaintiffs' alleged out-of-pocket damages if no corrective disclosure price drop facts exist. Such a holding would have

\footnotetext{
135. Pub. L. No. 105-353, 112 Stat. 3227 (codified as amended in scattered sections of 15 U.S.C.).

136. See supra note 107.

137. See Norman I. Singer, Statutes and Statutory Construction $\$ 5 A: 2$ (6th ed. 2002) (“It is now a commonplace that courts, not only of common law jurisdictions but also those which have codified statutory law as their base, participate in the lawmaking process. The commonplace, for which the Holmeses and the Cardozos had to blaze a trail in the judicial realm, assumes the rightness of courts in making interstitial law, filling gaps in the statutory and decisional rules, and at a snail-like pace giving some forward movement to the developing law."). Indeed, in point of fact, the Supreme Court recently took up this precise role in defining more clearly what the 104th Congress meant by "strong inference" when it used that term as part of a more stringent pleading standard for scienter in the PSLRA. See Tellabs, Inc. v. Makor Issues \& Rights, Ltd., 127 S. Ct. 2499, 2504 (2007). It is unclear why the Court felt comfortable pursuing this end in Tellabs but not in Dura. What is clear is that the Court has at least inferentially acknowledged via its pursuit of stricter pleading requirements in subsequent Rule 10b-5 holdings that it did not do enough in Dura to effectuate the congressional intent underlying the PSLRA.
}

138. See Jane S. Schecter, Metademocracy: The Changing Structure of Legitimacy in Statutory Interpretation, 108 Harv. L. Rev. 593, 594-95 (1997) ("[I]f the words used by the legislature are open to more than one-as is often the case in disputes about meaning that reach the courts-the court must look harder and longer and consider the legislative purpose behind the statute, the legislative history, and perhaps the canons of construction. Whether 'intent' or 'purpose' or some other similar measure serves as the benchmark, the traditional approach assumes a discoverable legislative design, and the court's cardinal obligation remains to identify and execute that design.... [T] he traditional approach to statutory interpretation, ... focuses judicial attention on the dispositive 'legislative intent.' . . [T] his conception gives judges clear marching orders. If the words of the statute unambiguously reflect legislative intent, the court should go no further.").

139. Presumably, this is because the Court did not view the PSLRA's pronouncement that a loss causation element existed as a loophole or inconsistency. It was at least ambiguous, and possibly inconsistent. As discussed above, the PSLRA was a document that purported to address the strike suit problem by, among other mechanisms, adjusting the pleading standards for Rule $10 \mathrm{~b}-5$ elements. See supra note 8 . In announcing that a new element must be pled, but not mentioning the extent to which it must be so pled, the PSLRA created an ambiguity. See supra note 107. 


\section{Thomas F. Gillespie III}

been consistent with the language of the PSLRA. ${ }^{140}$ Indeed, the damages cap proscribed by the PSLRA which includes a ninety-day look-back period was seemingly crafted with a corrective disclosure price drop model in mind. ${ }^{141}$ More importantly, however, it would have struck the proper balance between the competing interests in play in Rule 10b-5 litigation.

If the Court had held as I propose in this section, it might have struck an appropriate balance between creating pleading standards that facilitate the dismissal of strike suits and ensuring that legitimate claims proceed to trial. There are two policy-based arguments for the adoption of my proposed holding. One, it creates a workable standard that lower courts should be able to understand easily and apply uniformly. Second, the proposed holding should prove to be sufficiently flexible, such that it allows lower courts to continue to develop their own jurisprudence when managing special fact scenarios in the common law tradition, from which the private Rule $10 \mathrm{~b}-5$ claim originated. Additionally, though there is some debate about whether requiring a corrective disclosure price drop is prudent, it is clear that it is a very effective way to demonstrate loss causation. ${ }^{142}$ Indeed, most commentators seem to take issue with the proposition that demonstrating loss causation via a corrective disclosure price drop is the only way to do so, rather than with the idea that it is the best way. ${ }^{143}$ Thus, the proposed holding allows room for other factual scenarios, while encouraging plaintiffs to plead in a universally accepted way, cutting down on confusion without sacrificing flexibility.

Some commentators criticize this position as too lax because it would encourage corporate wrongdoers to try to escape liability by manipulating how they release information. These commentators argue that corporations would employ so-called leak-out or time-release strategies to ensure that no significant price drop could be

140. See supra, notes 8, 43; see also Olazabal, supra note 7, at 360-61 (observing that Congress implicitly endorsed the use of a corrective disclosure method for establishing loss causation in the legislative history of the PSLRA) ("[T]ypically, in an action involving a fraudulent misrepresentation or omission, the investor's damages are presumed to be the difference between the price paid for the security and the price of the security on the day the corrective information gets disseminated to the market." (citation omitted)).

141. See 15 U.S.C. $\$ 78 \mathrm{u}-4(\mathrm{e})(1)(2000)$.

142. See Fox, supra note 23 , at 855 (arguing that where a shareholder sells their shares before a corrective disclosure, they probably recouped all of their inflationary premium such that they have no injury and should be excluded from the plaintiffs class); see also supra note 141. But see, Thorsen et al., supra note 35, at 107 (" $[\mathrm{T}]$ he absence of a stock price reaction to a revelation of fraud does not mean there was no inflation and does not mean that there was no dissipation of the inflationary component of [the] price.").

143. See Fox, supra note 23, at 852 (arguing that one could just as easily measure the extent to which the price increased when the misrepresentation or omission was made if no corrective disclosure ever materializes); Thorsen et al., supra note 35, at 109-12 (discussing the merits of event studies and how they can be used when there is no corrective disclosure to demonstrate how a plaintiff's stock price was artificially inflated due to a defendant's misrepresentation). But see Burch, supra note 75, at 391-92 (discussing the inherent problems with event studies, e.g., that event studies can illustrate how a given securities price moved relative to the market, but it cannot show why it did so). 
contemporaneously linked with a corrective disclosure. ${ }^{144}$ Such a development, they argue, is contrary to the deterrence function of a private Rule $10 \mathrm{~b}-5$ action and would lead to degradation of the public's confidence in the reliability of U.S. financial markets. ${ }^{145}$ This argument is misplaced, however, and confuses the purpose of a private Rule 10b-5 action with that of its parent-a regulatory or SEC instituted $10 \mathrm{~b}-5$ action. The reason that a private Rule $10 \mathrm{~b}-5$ claim was implied from the SEC's Rule 10b-5 was to create a vehicle for wronged plaintiffs to obtain redress for their financial injuries, not to supplement the deterrent effect of the regulatory action itself. ${ }^{146}$ Moreover, even if private Rule $10 \mathrm{~b}-5$ claims have some deterrent effect, that effect is quite small in comparison to the federal regulatory actions and criminal proceedings aimed solely at that end. ${ }^{147}$ Thus, there appear to be more good reasons to steer plaintiffs toward utilizing a corrective disclosure paradigm in alleging and proving loss causation than not. As such, the Dura Court should have adopted a holding similar to the one proposed in this Note and created a paradigm where a workable standard for demonstrating loss causation is encouraged but not required. Such a holding would have been consistent with past precedent and the PSLRA. It also would have enabled the loss causation element to have the filtering, proximate cause-like effect it was intended to have.

\section{v. CONCLUSION}

The Dura Court's decision was generally a disappointment because it did not provide lower courts with needed guidance and clarity. Dura did some good by further defining what is meant by loss causation and, at least theoretically reducing the number of potential plaintiffs within the proverbial strike suit Rule $10 \mathrm{~b}-5$ securities fraud class. Unfortunately, this last development is probably only theoretical because (1) few securities fraud lawsuits proceed beyond the pre-trial stage, and (2) Dura at least implicitly suggests that loss causation need be pled only to a notice pleading standard. These facts operate together to make Dura's substantive holding distinctly less relevant. The Court was well aware of these realities and could have held that loss causation must be pled with particularity, similar to other elements

144. See Burch, supra note 75 , at 360 (arguing that after Dura, corporations may bundle good news with bad news in an effort to avoid a corrective disclosure and get away with making fraudulent misrepresentations about their stock price).

145. See Fox, supra note 23 , at 871-72 (discussing the deterrent effect of private suits and arguing that the rule should not be eased).

146. See Blue Chip Stamps v. Manor Drug Stores, 421 U.S. 723, 731-49 (1975) (holding that only defrauded purchasers or sellers of securities have standing in a private cause of action under Rule $10 \mathrm{~b}-5$ and that the creation of a private cause of action is not intended to shift the SEC's enforcement burdens under the rule to the public at large).

147. Indeed, the data suggests that the SEC, the NASD, the Department of Justice, and the exchanges are responsible for the majority of any deterrent effect that can be observed. See Burch, supra note 75 , at 395 (observing that from 2000-2002 only 205 securities fraud class action suits were brought, while over 5,000 suits were brought by various securities regulatory bodies and agencies). See generally Sarbanes-Oxley Act of 2002, Pub. L. No. 107-204, 116 Stat. 745 (codified as amended in scattered sections of 11, 15, 18,28, and 29 U.S.C.). 
described within PSLRA. Moreover, it could have done so in a way that provided lower courts with guidance via a workable standard, but still left room to foster development of the claim consistent with its common law tradition. If it had done so, the Court would have taken a very meaningful step toward effectuating the congressional intent that underlies the PSLRA and American securities laws generally. Unfortunately, the Court did not think such affirmative guidance was necessary and instead opted to leave many of the issues presented in Dura for adjudication on another day. 